\title{
Frequency of headache among the employees of a rubber company in the state of São Paulo, Brazil
}

\section{Frequência de cefaleia em trabalhadores de uma empresa de borracha no Estado de São Paulo, Brasil}

\author{
Juliana Stuginski-Barbosa', José Geraldo Speciali" \\ Faculdade de Medicina de Ribeirão Preto (FMRP), Ribeirão Preto, São Paulo, Brazil
}

KEY WORDS:

Occupational health.

Headache.

Migraine disorders.

Tension-type headache.

Absenteeism.

\section{PALAVRAS-CHAVE:}

Saúde do trabalhador.

Cefaleia.

Transtornos de enxaqueca.

Cefaleia tipo tensional.

Absenteísmo.

\begin{abstract}
CONTEXT AND Objective: Primary headaches may be responsible for absenteeism and a fall in the yield and productivity of work. The aim of this study was to establish the presence and frequency of primary headache among employees of a rubber shoe sole company, and its link to absenteism. DESIGN AND SETIING: Cross-sectional study carried out with help from the staff of the medical and social department of a rubber factory located in the municipality of Franca, São Paulo.

METHOD: A questionnaire on headache characteristics was distributed to all employees. The returned and completed questionnaires were divided into two groups: with and without reports of headache. The headaches were classified into four main groups: migraine, tension-type headache (TH), cluster headache and others. In terms of the reported frequency, headaches were also classified as chronic daily headache (CDH). RESULTS: The number of valid questionnaires was 392 (59\%); $80.9 \%$ were from male and $19.1 \%$ from female employees. Headaches were reported by 120 subjects (30.6\%), with $17.4 \%$ belonging to the migraine group and $8.9 \%$ to the $T H$ group. Migraine was more frequent $(p<0.001)$ among all participants and also among the women $(p<0.05)$. TH was more frequent among the men $(p<0.05)$. CDH was identified in 14 individuals (3.6\%).

CONCLUSIONS: Headache was a common problem among the employees of this company and was a cause of absenteeism for $8.7 \%$ of the respondents to the questionnaire.
\end{abstract}

\section{RESUMO}

CONTEXTO E Objetivo: Cefaleias primárias podem ser causa de absenteísmo, e de queda no rendimento e na produtividade do trabalho. 0 objetivo do estudo foi estabelecer a presença e frequência de cefaleia primária em funcionários de uma empresa de solados de borracha,e sua relação com absenteísmo.

TIPO DE ESTUDO E LOCAL: Estudo transversal realizado com a ajuda do pessoal do departamento médico e social de uma empresa localizada no município de Franca, São Paulo.

MÉTODO: Um questionário sobre as características da cefaleia foi distribuído a todos os funcionários. Os questionários devolvidos e preenchidos foram divididos em dois grupos: com e sem relato de cefaleia. As cefaleias foram classificadas em quatro grupos principais: migrânea, cefaleia do tipo tensional (CT), cefaleia em salvas e outras cefaleias. Através da frequência da cefaleia, foi possível a classificação em cefaleia crônica diária (CCD).

RESULTADOS: 0 número de questionários válidos foi de 392 (59\%), 80,9\% questionários eram de funcionários do gênero masculino, e 19,1\%, do gênero feminino. Cento e vinte (30,6\%) dos funcionários relataram apresentar cefaleia, sendo que $17,4 \%$ pertenceram ao grupo migrânea e 8,93\% ao grupo CT. 0 diagnóstico de migrânea foi o mais frequente $(p<0,001)$ dentre todos, e também entre as mulheres $(p<0,05)$. 0 diagnóstico de $C \pi$ foi mais frequente entre os homens $(p<0,05)$. CCD foi identificada em 14 indivíduos $(3,6 \%)$.

CONCLUSÕES: Cefaleia é um problema frequente entre os funcionários da empresa participante da pesquisa sendo a causa de absentismo em $8,7 \%$ dos que responderam o questionário.

\section{INTRODUCTION}

Epidemiological studies usually start from clinical observations that generate data and allow hypotheses to be established. ${ }^{1}$ Populationbased epidemiological studies indicate that the prevalence of chronic pain ranges from $19 \%$ to $46 \%$ depending on the population, and the age and occupation of the subjects. ${ }^{2,3}$ The prevalence of chronic pain among the employees of a Brazilian university was $61.4 \%$, and the head was the most prevalent site of pain $(26.7 \%) .{ }^{4}$ High prevalence of pain, including primary headaches, may contribute towards greater demand for treatment in neurologists' offices.

In view of the impact of pain and its association with depression, anxiety and even mortality, identification of risk groups presenting pain as a symptom is extremely important. ${ }^{5}$

The combination of clinical observations and epidemiological investigations is particularly important in studies relating to headache. Patients who seek treatment at specialized centers are systematically different from individuals with headache in the general population,

'MSc. Surgeon Dentist, Department of Neurosciences, Faculdade de Medicina de Ribeirão Preto, Universidade de São Paulo (FMRP-USP), Ribeirão Preto, São Paulo, Brazil.

"MD. Associate Professor of Neurology, Department of Neurosciences, Faculdade de Medicina de Ribeirão Preto, Universidade de São Paulo (FMRP-USP), Ribeirão Preto, São Paulo, Brazil. 
who often do not receive a diagnosis or treatment and therefore are not the target of clinical observations. ${ }^{1}$

In a study conducted in the United States, 30,000 workers were interviewed about the impact of health on work. In that study, the total cost of health problems was estimated as 250 billion dollars per year, and 60 billion dollars was attributed to problems relating to pain. Among these, headache produced a cost of about 20 billion dollars in terms of loss of productivity. ${ }^{6}$

Primary headaches may be responsible for absenteeism, a fall in the yield and productivity of work or study and loss of leisure days, as well as affective and relationship problems. ${ }^{7-9}$

Primary headache is considered to be pain that occurs in the head without a temporal relationship with another disorder that might be recognized as a cause of headache. The most prevalent primary headaches are migraine and tension-type headache (TTH), which are classified in groups 1 and 2 of the International Headache Classification. ${ }^{10}$

\section{OBJECTIVE}

The objective of the present study was to observe the frequency of primary headaches, especially migraine and TTH, among the employees of a rubber shoe sole factory located in the interior of the state of São Paulo, and the absenteeism linked to it.

\section{METHODS}

This cross-sectional study was carried out with help from the staff of the medical and social department of a company located in the municipality of Franca, São Paulo, which manufactures rubber products and is currently considered to be one of the most important industrial complexes in the footwear sector (Componam Componentes para Calçados Ltda).

A self-administered questionnaire (Annex 1) drawn up by professionals at the Headache and Craniofacial Pain Outpatient Clinic of the University Hospital, Faculdade de Medicina de Ribeirão Preto, Universidade de São Paulo (HCFMRP-USP), ${ }^{11}$ was distributed to all the employees, who were instructed to fill it out at home. The questionnaire contained items regarding demographic data and 24 questions about the topic under investigation.

The company had 666 production employees over the age of 18 years who were currently working, among whom the questionnaires were distributed. These workers were organized into four different shifts. The minimum sample size was calculated assuming a standard error of 5\%, 95\% confident interval and estimated response rate of 50\%. This resulted in a minimum sample size of 244 participants.

To avoid embarrassment and maintain anonymity, study participants were not required to state their names on the questionnaire, although they could so optionally. One question was open and the remaining ones were multiple choice questions. The question "do you habitually have headaches?" was defined in order to assign the employees to groups with or without headache. If an employee reported the presence of headache, he was then asked to answer questions regarding the characteristics of the disorder such as frequency, duration, location, intensity and related symp- toms. The questions were drawn up in such a way as to enable classification of headaches in accordance with the criteria of the International Classification of Headache Disorders (Headache Classification Subcommittee of the International Headache Society). ${ }^{10,11}$ A question about absenteeism was added to the questionnaire. The question about headache intensity required choosing a value between 0 (absence of pain) and 10 (the strongest pain the person could feel).

After filling out the questionnaire, the employees deposited it in a box located in the company's social department. Returning the questionnaire was optional and was supposed to occur within 15 days.

The study was approved by the Ethics Committee of Santa Casa de Franca under no. 022-2008 and complied with the standards and regulations for research involving human beings issued by the National Health Board (Conselho Nacional de Saúde; CNS) under its Resolution 196/96. A consent form was delivered to each participant for signing together with the questionnaire. A telephone number and an electronic address were available so that the employees could contact the investigators if they had any queries. The employees also had the possibility of clarifying their queries through the company's medical and social department.

The questionnaires that were filled out and returned were divided into two groups: those that reported habitual headaches and those that did not. On the basis of the characteristics reported by the employees, it was possible to classify the headaches into four major groups: migraine, tension-type headache (TTH), cluster headache and other headaches. Questionnaires containing data that were not enough to characterize the type of headache were assigned to a fifth group named insufficient data.

For migraine, the required characteristics were: headache attacks lasting 4-72 hours (untreated or unsuccessfully treated); presence of at least two of the following characteristics: unilateral location, pulsating quality, moderate or severe pain intensity, aggravation by or causing avoidance of routine physical activities; and, during the headache, at least one of the following: nausea and/or vomiting, photophobia and phonophobia. For TTH, the required characteristics were: headache lasting from 30 minutes to 7 days; presence of at least two of the following characteristics: bilateral location, pressing/tightening (non-pulsating) quality, mild or moderate intensity without aggravation by routine physical activity such as walking or climbing stairs; and no nausea or vomiting (anorexia may occur) and no more than one occurrence of photophobia or phonophobia. For cluster headache, the required characteristics were: severe or very severe unilateral orbital, supraorbital and/ or temporal pain lasting 15-180 minutes if untreated, accompanied by at least one of the following: ipsilateral conjunctival injection and/or lacrimation, ipsilateral nasal congestion and/or rhinorrhea, ipsilateral eyelid edema, ipsilateral forehead and facial sweating, ipsilateral miosis and/or ptosis, and a sense of restlessness or agitation.

On the basis of the frequency reported, it was also possible to determine the number of employees who had chronic daily headache $(\mathrm{CDH})$, and the groups were also subdivided into episodic migraine, chronic migraine, episodic TTH and chronic TTH.

The variables regarding the demographic data and smoking habit were compared between the groups. 
The Shapiro-Wilk test was applied to determine the distribution of the age variable. The Mann-Whitney test was used to compare ages between the groups and the t-test for two independent samples was used to compare the intensity of headache between the groups. The chisquare test or Fisher exact test was applied to analyze categorical variables according to the frequency expected in the cells. The hypothesis test for two proportions was applied to compare the data with those reported in the literature.

\section{RESULTS}

A total of 666 questionnaires were distributed and 393 of them (59\%) were returned. One questionnaire was returned without being filled out and 392 were valid; 317 (80.87\%) were returned by male employees and 75 (19.13\%) by female employees.

The overall mean age was 35.4 years, the male mean age was 36.6 years and the female mean age was 30.5 years. The male mean age was significantly greater than the female mean age $(\mathrm{P}<0.001) ; 10.5 \%$ of the participants did not state their age.

Only $4.2 \%$ of the individuals (16) did not answer the questions regarding headache correctly and were therefore not assigned to any of the headache groups. The remaining subjects were divided into two groups, i.e. subjects who reported habitual headaches and subjects who did not. There were 120 employees (30.61\%) with reports of suffering from headache. Table 1 lists demographic information (gender, schooling, marital status and age range) and smoking habit data for both groups. The mean age of the subjects with headaches was 33.5 years and the mean age of the subjects without headaches was 36.3 years, with no significant difference between the groups ( $\mathrm{P}>0.05)$. Seventy-eight men (24.6\%) and 42 women (56\%) reported suffering from headaches. The proportion of women with headache was significantly greater than the proportion of men $(\mathrm{P}<0.001)$. There was no significant difference in schooling, marital status, age range or smoking habit between subjects with and without headaches $(\mathrm{P}>0.10)$.

Table 2 presents the distribution of the subjects (divided according to gender) who reported headaches in accordance with the headache diagnoses of the International Headache Classification. Among the employees who answered the questionnaire $(\mathrm{n}=392), 17.3 \%$ belonged to the migraine group and $8.9 \%$ to the TTH group. The diagnosis of migraine was significantly more frequent $(\mathrm{P}<0.001)$ and was proportionally more frequent among the women $(\mathrm{P}<0.05)$, whereas the diagnosis of TTH was more frequent among the men $(\mathrm{P}<0.05)$.

Table 3 presents the data regarding the frequency of headache according to diagnostic group. Headaches occurred frequently, on one to seven days per month in $40 \%$ of the subjects who reported it. CDH was identified in 14 individuals (3.57\%), chronic migraine in $12(3.06 \%)$ and chronic TTH in two $(0.51 \%)$. Chronic migraine was proportionally and significantly more frequent than chronic TTH $(\mathrm{P}<0.05)$.

All the subjects assigned values to the intensity of headache, with a mean of 5.94 and a median of 6 . Figure 1 illustrates the intensity of pain in the different headache groups. Subjects in the migraine group had significantly greater headache intensity than did subjects with TTH $(\mathrm{P}<0.001)$.

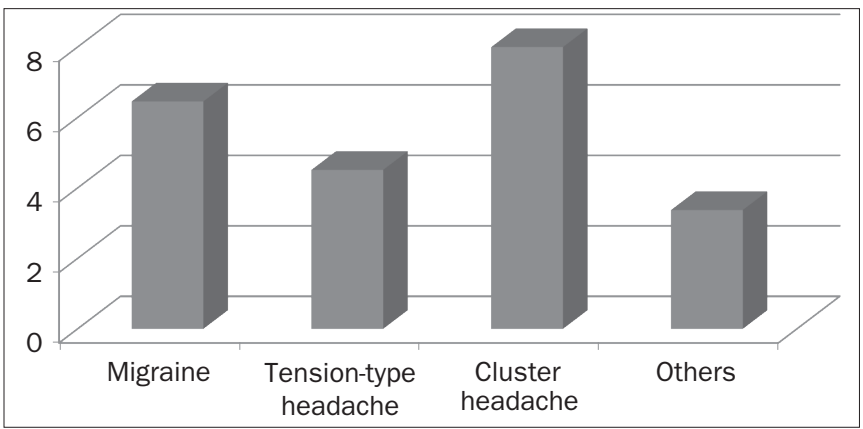

Figure 1. Headache intensity by subgroup according to the International Classification of Headache (IHS-II, 2004).

Table 1. Sample characteristics regarding the presence of headache

\begin{tabular}{|c|c|c|c|c|}
\hline & \multicolumn{2}{|c|}{ Headache } & \multirow{2}{*}{ Total - n (\% } \\
\hline & & Yes - n (\%) & No $-n(\%)$ & \\
\hline \multirow{2}{*}{ Gender } & Male & $78(24.6)^{*}$ & $239(75.4)$ & $317(100)$ \\
\hline & Female & $42(56)^{*}$ & $33(44)$ & $75(100)$ \\
\hline Total & & $120(30.6)$ & $272(69.4)$ & $392(100)$ \\
\hline \multirow{6}{*}{ Schooling } & Not declared & $7(46.7)$ & $8(53.3)$ & $15(100)$ \\
\hline & Up to $4^{\text {th }}$ grade & $2(11.1)$ & $16(88.9)$ & $18(100)$ \\
\hline & Elementary school completed & $17(32)$ & $36(68)$ & $53(100)$ \\
\hline & High school completed & $67(32.2)$ & $141(67.8)$ & $208(100)$ \\
\hline & Technical course & $6(21.4)$ & $22(78.6)$ & $28(100)$ \\
\hline & Higher education & $21(30)$ & $49(70)$ & $70(100)$ \\
\hline Total & & $120(30.6)$ & $272(69.4)$ & $392(100)$ \\
\hline \multirow{5}{*}{$\begin{array}{l}\text { Marital } \\
\text { status }\end{array}$} & ND & $10(32.2)$ & $21(67.8)$ & $31(100)$ \\
\hline & Married & $73(29.5)$ & $174(70.5)$ & $247(100)$ \\
\hline & Single & $32(31)$ & $71(69)$ & $103(100)$ \\
\hline & Divorced & $3(33.3)$ & $6(66.7)$ & $9(100)$ \\
\hline & Widowed & $2(100)$ & $0(0)$ & $2(100)$ \\
\hline Total & & $120(30.6)$ & $272(69.4)$ & $392(100)$ \\
\hline \multirow{7}{*}{ Age range } & $18 \mid-20$ & $2(33.3)$ & $4(66.7)$ & $6(100)$ \\
\hline & $20 \mid-30$ & $24(32.4)$ & $50(67.6)$ & $74(100)$ \\
\hline & $30 \mid-40$ & $37(35)$ & $69(65)$ & $106(100)$ \\
\hline & $40 \mid-50$ & $28(28.5)$ & $70(71.5)$ & $98(100)$ \\
\hline & \begin{tabular}{l|l|}
50 & -60 \\
\end{tabular} & $15(25)$ & $45(75)$ & $60(100)$ \\
\hline & $\geq 60$ & $1(14)$ & $6(86)$ & $7(100)$ \\
\hline & Age not mentioned & $13(31.7)$ & $28(68.3)$ & $41(100)$ \\
\hline Total & & $120(30.6)$ & $272(69.4)$ & $392(100)$ \\
\hline \multirow{2}{*}{ Smoker } & Yes & $9(25.7)$ & $26(74.3)$ & $35(100)$ \\
\hline & No & $111(31)$ & $246(69)$ & $357(100)$ \\
\hline Total & & $120(30.6)$ & $272(69.4)$ & $392(100)$ \\
\hline Total & & $120(30.6)$ & $272(69.4)$ & $392(100)$ \\
\hline
\end{tabular}

*significant difference (chi-square test, $P<0.001$ ); no significant difference (chi-square test, $P>0.05$ ).

Table 2. Groups of headache diagnoses by gender, in accordance with the International Classification of Headaches (2004), in the total sample $(\mathrm{n}=392)$

\begin{tabular}{|c|c|c|c|}
\hline & \multicolumn{2}{|c|}{ Gender } & \multirow{2}{*}{ Total } \\
\hline & Male & Female & \\
\hline \multicolumn{4}{|c|}{ Headache subtype } \\
\hline Migraine* & $37(9.5 \%)$ & $31(7.9 \%)^{\dagger}$ & $68(17.4 \%)$ \\
\hline Tension-type headache & $28(7.2 \%)^{\ddagger}$ & $7(1.8 \%)$ & 35 (8.9\%) \\
\hline Cluster headache & $0(0.0 \%)$ & $1(0.2 \%)$ & $1(0.2 \%)$ \\
\hline Other headaches & $9(2.3 \%)$ & $2(0.5 \%)$ & $11(2.8 \%)$ \\
\hline Insufficient data & $4(1.0 \%)$ & $1(0.2 \%)$ & $5(1.2 \%)$ \\
\hline Total & $78(20 \%)$ & $42(10.6 \%)$ & $120(30.6 \%)$ \\
\hline
\end{tabular}


Table 3. Frequency of each headache subtype classified in accordance with the criteria of the International Classification of Headaches (IHS-II), among patients with headache $(n=120)$

\begin{tabular}{lcccccc}
\hline Frequency & Migraine* $^{*}$ & Tension-type headache* & Cluster headache & Other headaches & Insufficient data & Total \\
\hline Every day of the month & 3 & 0 & 0 & 0 & 0 & 0 \\
\hline$>15$ days per month & 9 & 2 & 0 & 0 & 1 \\
\hline 8-15 days per month & 10 & 5 & 0 & 3 & 1 \\
\hline 1-7 days per month & 28 & 17 & 0 & 2 & 1 \\
\hline 4-11 attacks per year & 11 & 6 & 1 & 4 & 0 \\
\hline$<4$ attacks per year & 7 & 5 & 0 & 2 & 0 \\
\hline Not declared & 0 & 0 & 0 & 0 & 3 \\
\hline Total & 68 & 35 & 1 & 11 & $5(15.8 \%)$ \\
\hline
\end{tabular}

"Chronic migraine (more than 15 days per month) was proportionally and significantly more frequent than chronic tension-type headache (chi-square test, $\mathrm{P}<0.05)$.

Ten $(8.3 \%)$ of the 120 subjects in the headache group (six women and four men) reported having missed work because of the condition. Nine of these belonged to the migraine group and one to the cluster headache group.

\section{DISCUSSION}

Among the employees, $30.61 \%$ had headaches, and the most frequent forms were migraine and TTH. About $17 \%$ of the workers studied $(\mathrm{n}=392)$ were assigned to the migraine group. This result was similar to that reported by Pop et al. in a study conducted in a Dutch factory in which $15 \%$ of the employees had migraine. ${ }^{12}$

Migraine is a recurrent primary headache that manifests as crises lasting for four to 72 hours, preferentially of unilateral localization. It has a pulsatile nature, with moderate or strong intensity exacerbated by physical activity and associated with nausea and/or vomiting or photophobia or phonophobia. It is divided into two main subtypes: migraine with aura and migraine without aura. ${ }^{10}$

TTH is the most common type of primary headache and, at the same time, the least studied. TTH is divided into two groups: episodic (ETTH) and chronic (CTTH). In ETTH, the pain typically occurs as a sensation of weight or pressure of weak to moderate intensity and has a bilateral frontotemporal or occipital location. It does not become worse with physical activity and is not accompanied by nausea, but may involve photophobia or phonophobia. CTTH has the same characteristics as ETTH, but occurs on more than 15 days per month and lasts for more than three months, affecting patients with a history of ETTH. ${ }^{10}$

Migraine and TTH are also the most prevalent types in population studies. In a study in the city of Ribeirão Preto, the prevalence of primary headaches was found to be $49.9 \%$, with predominance in the female gender $(63.8 \%)$. The most prevalent diagnoses were ETTH (16.2\%), migraine without aura (13.9\%) and migraine with aura $(5.1 \%)$. Both migraine and ETTH were more prevalent among women, with migraine affecting $28 \%$ of women and $9.9 \%$ of men, and ETTH affecting $23.2 \%$ of women and $9.5 \%$ of men. ${ }^{11}$

Because patients with TTH present less intense headaches with a smaller individual impact, they tend to neglect their pain, ${ }^{13}$ and this may have contributed towards failure to respond to the questionnaire in the present study. It may also explain the different percentages of TTH that have been found in different populations. In the present study, migraine was significantly more frequent among women and TTH was more frequent among men.

Another type of primary headache that can be characterized in a questionnaire is cluster headache. This type of headache involves strictly unilateral strong pain crises in the orbital, supraorbital and/ or temporal region that last for 15 to 180 minutes. The crises are accompanied by one or more autonomic symptoms ipsilaterally to the pain, such as conjunctival hyperemia, tearing, nasal congestion, rhinorrhea, sudoresis on the forehead and face, miosis, ptosis and palpebral edema. During the crises, most patients are restless or agitated. ${ }^{10}$ Cluster headache is uncommon in comparison with migraine, and its population-based prevalence is lower than $1 \%$, with predominance among males. ${ }^{14}$ In the present study, the single subject assigned to the cluster headache group was a female.

Regarding the frequency of headache crises, $40 \%$ of the subjects ( $41.2 \%$ belonging to the migraine group and $48.6 \%$ belonging to the TTH group) reported that they suffered headaches on one to seven days per month. This result is similar to the findings of Bigal et al., who observed a crisis frequency of two to four times a month in $47 \%$ of the employees with migraine. ${ }^{15}$

Very frequent crises (occurring on more than 15 days per month) characterize a group of headaches called chronic daily headache $(\mathrm{CDH}) .{ }^{16}$ The presence of $\mathrm{CDH}$ affects the quality of life, with an important impact on individuals' productive, social and emotional characteristics. ${ }^{17}$ The prevalence of $\mathrm{CDH}$ in the population ranges from 4.1 to $6.4 \% .{ }^{18,19}$ In the study conducted on the population of Ribeirão Preto, $2.6 \%$ of the individuals presented CDH: $2 \%$ 
with chronic migraine and $0.6 \%$ with chronic TTH. ${ }^{11}$ In the present study, 14 subjects (3.57\%) fulfilled the criteria for $\mathrm{CDH}$, with no significant difference compared with the proportions reported in the literature $(\mathrm{P}>0.05)$. Based on clinical observations, chronic migraine and TTH are believed to progress gradually from their episodic to their chronic forms. ${ }^{20}$ Among these 14 individuals (3.57\%), $12(3.06 \%)$ fulfilled the criteria for chronic migraine, and this result was similar to what was reported in the study by Queiroz et al. ${ }^{19}$ Thus, chronic migraine was significantly more frequent than chronic TTH.

$78.1 \%$ of the patients with primary headache report that headache interferes with their general living activities and $41.7 \%$ report interference with their quality of life. ${ }^{11}$

Individuals' ability to work is definitely affected by their health condition. Losses in productivity can be evaluated both in terms of absenteeism and presenteeism. Absenteeism refers to missed days of work, leaves of absence and work disability, while presenteeism refers to reduction of productivity due to disease by an employee who remains present on the job. Presenteeism is estimated to represent $86 \%$ of the loss of productivity and absenteeism to represent $16 \%$ of it. ${ }^{21}$

The presence of headache, especially migraine, can be considered to be a risk factor for loss of productivity on the job. The expenses relating to headache can be direct (expenses relating to the healthcare system) and indirect (losses due to missed days of work, reduced productivity and fewer opportunities for promotion and education). ${ }^{22-24}$

Among the patients with headache, migraineurs experience a high level of pain and disability. Less than $10 \%$ of them state that they are fit for work during the crises. ${ }^{1}$ The prevalence of migraine is higher between 22 and 66 years of age, thus coinciding with the time of peak productivity of the affected subjects. At 30 years of age, women tend to present higher intensity and frequency of crises, and this may increase the risk that migraine may interfere with productivity. ${ }^{25,26}$

A study conducted on workers in France reported that the presence of migraine resulted in a relative risk of 1.79 for the reduction of attention and a risk of 1.46 for the reduction of time at work. ${ }^{27}$ A study conducted at the University Hospital of Ribeirão Preto estimated a loss of approximately 500,000 dollars in a single year due to the reduced productivity of its employees during migraine crises. ${ }^{15}$

Even though impairment of work was reported, absenteeism was not frequent (8.7\%) among the participants; $90 \%$ of those who reported missing work due to headache belonged to the migraine group. Headache also generated loss of productivity, even when the employees went to work with a headache. These occurrences cause losses both to the company and to the workers.

The instrument selected for data collection in the present study was a questionnaire. Such instruments have a good cost/benefit ratio and present certain advantages such as low cost and rapidity of use, provision of direct knowledge of the realities, absence of investigator's bias, and guaranteed participant anonymity. Asking the subjects to fill out the questionnaire individually at home may have been a favorable point, since it gave the employees more time and availability to respond.

However, the present instrument also had some limitations, and one of them was the large number of questions that were asked about the topic under investigation, which may have discouraged potential responders. The absence of the investigator while the questionnaire was being answered was minimized by the researchers' offer to clarify any queries relating to filling it out. The response rate was as expected but because it was not $100 \%$, this may have compromised the representativeness of the data collected. Only one questionnaire was returned unanswered. The question with the largest number of missed replies (10.5\%) was the one relating to the subject's age. However, this did not impair the results obtained.

Studies conducted in the United States have indicated that, even though epidemiological surveys have shown that the prevalence of migraine has stabilized over the years, the number of patients diagnosed has increased. This demonstrates the efforts that have been made by clinicians and neurologists towards diagnosing and treating this very common headache. However, despite these efforts, $50 \%$ of all migraineurs never receive a diagnosis. The first step needed to change this picture is to identify these individuals and encourage them to seek adequate treatment for their problem. ${ }^{1}$

Knowledge about the impact of the disease can help healthcare professionals to understand the severity of headaches and how the condition affects their patients' lives. Better communication between patients and health professionals regarding the disability relating to headaches can potentially improve these individuals' medical treatment. In turn, improved treatment can reduce emergency care, abuse of medication and loss of productivity. ${ }^{9}$

Implementation of educational programs for physicians and company employees in order to teach them about headaches may help to improve the understanding of this symptom. ${ }^{12}$ In one example, there was a significant improvement in quality of life, a reduction in the disability associated with headaches and stimulation of the use of self-care among the employees who participated in an educational program. ${ }^{28}$ Information about the employees' clinical situation made it possible for the company's medical and social department to plan preventive approaches directed towards the problems, as well as reducing their impact on work.

Investments by companies in educating their physicians and employees about the aspects of headache discussed here may transform the damage into gains. In addition, these employees' quality of life will improve, thereby transforming them into individuals who are more productive and better satisfied with the activities that they perform.

\section{CONCLUSION}

Headache was a frequent problem among the employees of the company participating in the present study, and was a cause of absenteeism among $8.7 \%$ of those who answered the questionnaire. 
Annex 1. Headache questionnaire (original)

\section{QUESTIONÁRIO DE CEFALEIA}

1. Você fuma? ( ) sim ( ) não

Há quanto tempo anos

Quantos cigarros por dia?

2. Você toma café diariamente? ( ) sim ( )não

Quantas xícaras por dia?

3. Você costuma ter dor de cabeça? ( ) sim （ ) não Apenas se você respondeu sim, continue o questionário.

4. Há quanto tempo você tem dor de cabeça?

( ) menos de 3 meses ( ) menos de 2 anos

( ) de 2 a 5 anos ( ) de 6 a 10 anos

( ) mais de 10 anos

5. Você relaciona o início da sua dor com algum período/ fato/acontecimento citado abaixo?

( ) NÃO

SIM: ( ) infância ( ) gravidez ( ) adolescência ( ) menopausa ( ) idade adulta

( ) outro. Qual?

6. Qual é a frequência da sua dor de cabeça?

( ) todos os dias do mês

( ) entre 4 e 11 crises por ano

( ) mais de 15 dias por mês

( ) menos de 4 crises por ano

( ) entre 8 e 15 dias por mês

( ) entre 1 e 7 dias por mês

7. Quanto tempo dura, em média, a sua dor de cabeça, se você não tomar analgésico?

( ) menos que 4 minutos ( ) de 1 a 3 dias

( ) menos que 30 minutos ( ) mais que 3 dias

( ) menos que 2 horas ( ) dia e noite sem parar

( ) menos que 4 horas

( ) de 4 a 24 horas

8. Você já foi acordado durante a noite pela dor de cabeça?

( ) não ( ) sim

9. Em que lugar a cabeça costuma doer?

(Você pode assinalar mais de uma resposta)

( ) só de um lado da cabeça

( ) na nuca

( ) dos dois lados da cabeça

( ) a cabeça toda

10. Como é o tipo da sua dor de cabeça?

( ) latejante, pulsátil, como um coração batendo

( ) em queimação, ardente

( ) em pontadas, agulhadas

( ) como um choque

( ) como um peso em cima da cabeça

( ) pressão, como um aperto na cabeça
11. De 0 a 10, sendo zero a ausência de dor e 10 a dor mais forte que você pudesse sentir, qual é a intensidade da sua dor de cabeça?

$\begin{array}{cccccccc}\text { sem dor } & 0 & 1 & 2 & 3 & 4 & 5 & 6\end{array}$

12. Quanto tempo leva para sua dor chegar na intensidade máxima?
( ) menos de um minuto
( ) menos de 2
horas ( ) Mais de 2 horas

13. 0 quanto essa dor atrapalha as suas atividades do dia a dia?

( ) não atrapalha

( ) atrapalha um pouco mas não impede as atividades

( ) atrapalha muito, impede que faça as atividades

14. Você chega a faltar no trabalho por causa de dor de cabeça? ( ) não ( ) sim.

Quantos dias por ano?

15. Quando você está com dor, o esforço físico (subir escada, pegar peso, andar depressa, fazer tarefa doméstica):
( ) agrava a dor
( ) não agrava a dor

16. Quando você tem dor de cabeça, você prefere:

( ) ficar quieto em um lugar sem barulho

( ) mudar a atividade que está fazendo (ir tomar banho, conversar, por exemplo)

( ) fica agitado, andando de um lado para o outro

17. Quando você tem dor de cabeça: (Você pode assinalar mais de uma resposta)

( ) seu estômago enjoa ( ) o olho fica vermelho

( ) você vomita ( ) o olho fica inchado

( ) a luz incomoda ( ) o olho lacrimeja

( ) o barulho incomoda ( ) a pálpebra cai

( ) o nariz entope

( ) o nariz escorre

18. 0 que costuma provocar a sua dor de cabeça?

(Você pode assinalar mais de uma resposta)

( ) nervosismo, preocupação

( ) odores

( ) alimentos

( ) bebidas

( ) menstruação

( ) tosse, esforço físico ou atividade sexual

( ) outro. Qual?

19. Você percebe que vai ter dor de cabeça antes que a dor comece?

( ) não

( ) sim. Quanto tempo antes?

( ) menos que 1 hora

( ) até 24 horas antes

( ) outro

Qual?
20. Por quais sintomas você sabe que vai ter dor de cabeça ? (Você pode assinalar mais de uma resposta)

( ) alterações visuais

( ) formigamento no corpo ou em volta da boca

( ) dificuldade para falar

( ) tontura e/ou zumbido

( ) fica nervoso, inquieto, aflito

( ) fica triste, quieto, deprimido

( ) tem desejos por certos alimentos

( ) tem bocejos repetidos

( ) fraqueza em um dos lados do corpo

( ) outro. Qual?

21. Você sabe o nome da sua dor de cabeça ?

( ) não ( ) sim. Qual?

22. Você faz uso de remédios diariamente para evitar o aparecimento da dor de cabeça (tratamento profilático)?

( ) não

( ) sim. Qual(is) remédio(s)?

23. Na hora em que você está com dor de cabeça, você faz uso de remédios para aliviar a sua dor?

( ) não ( ) sim. Qual(is) remédio(s)?

Com que frequência?

( ) 3 dias ou menos por semana

( ) mais que 3 dias por semana

24. Na sua opinião, em que aspectos a dor de cabeça mais o atrapalha ou mais o preocupa?

25. Algum parente seu tem dor de cabeça?

( ) não ( ) sim. Quem? ( ) pai ou mãe

( ) filho/filha ( ) irmão/irmã

26. Você tem algum outro problema de saúde?

( ) $\operatorname{sim} \quad$ ( ) não

Se sim, qual?

\section{REFERENCES}

1. Lipton RB, Bigal ME. Ten lessons on the epidemiology of migraine. Headache. 2007;47 Suppl 1:S2-9

2. Breivik H, Collett B, Ventafridda V, Cohen R, Gallacher D. Survey of chronic pain in Europe: prevalence, impact on daily life, and treatment. Eur J Pain. 2006;10(4):287-333.

3. Neville A, Peleg R, Singer Y, Sherf M, Shvartzman P. Chronic pain: a population-based study. Isr Med Assoc J. 2008;10(10):676-80.
4. Kreling MCGD, Cruz DALM, Pimenta CAM. Prevalência de dor crônica em adultos [Prevalence of chronic pain in adult workers]. Rev Bras Enferm. 2006;59(4):509-13.

5. Edwards RR. Individual differences in endogenous pain modulation as a risk factor for chronic pain. Neurology. 2005;65(3):437-43.

6. Stewart WF, Ricci JA, Chee E, Morganstein D, Lipton R. Lost productive time and cost due to common pain conditions in the US workforce. JAMA. 2003;290(18):2443-54.

7. Stewart WF, Lipton RB, Kolodner K, Liberman J, Sawyer J. Reliability of the migraine disability assessment score in a population-based sample of headache sufferers. Cephalalgia. 1999;19(2):107-14; discussion 74. 
8. Stewart WF, Lipton RB, Whyte J, et al. An international study to access reliability of the Migraine Disability Assessment (MIDAS) score. Neurology. 1999;53(5):988-94.

9. Lipton RB, Stewart WF, Goadsby PJ. Headache-related disability in the management of migraine. Neurology. 2001;56(6 Suppl 1):S1-3.

10. Subcomitê de Classificação das Cefaleias da Sociedade Internacional de Cefaleia. Classificação internacional das cefaleias. $2^{\mathrm{a}} \mathrm{ed}$. Trad. Sociedade Brasileira de Cefaleia. São Paulo: Alaúde Editorial Ltda; 2006.

11. Gonçalves DA, Bigal ME, Jales LC, Camparis CM, Speciali JG. Headache and symptoms of temporomandibular disorder: an epidemiology study. Headache. 2010;50(2):231-41.

12. Pop PH, Gierveld CM, Karis HA, Tiedink HG. Epidemiological aspects of headache in a workplace setting and the impact on the economic loss. Eur J Neurol. 2002;9(2):171-4.

13. Vincent M, Rodrigues A, Oliveira GV, et al. Prevalência e custos indiretos das cefaléias em uma empresa brasileira [Prevalence and indirect costs of headache in a Brazilian Company]. Arq Neuropsiquiatr. 1998;56(4):734-43.

14. May A. Cluster headache: pathogenesis, diagnosis, and management. Lancet. 2005;366(9488):843-55.

15. Bigal ME, Fernandes LC, Moraes FA, Bordini CA, Speciali JG. Prevalência e impacto da migrânea em funcionários do Hospital das Clínicas da Faculdade de Medicina de Ribeirão Preto - USP [Migraine prevalence and impact in employees of the Hospital das Clínicas da Faculdade de Medicina de Ribeirão Preto - USP]. Arq Neuropsiquiatr. 2000;58(2B):431-6.

16. Silberstein SD. Chronic daily headache. J Am Osteopath Assoc. 2005;105(4 Suppl 2):23S29S.

17. Galego JCB, Moraes AM, Cordeiro JA, Tognola WA. Chronic daily headache: stress and impact on the quality of life. Arq Neuropsiquiatr. 2007;65(4b):1126-9.

18. Scher Al, Stewart WF, Liberman J, Lipton RB. Prevalence of frequent headache in a population sample. Headache. 1998;38(7):497-506.

19. Queiroz LP, Barea LM, Blank N. An epidemiological study of headache in Florianopolis, Brazil. Cephalalgia. 2006;26(2):122-7.

20. Midgette LA, Scher Al. The epidemiology of chronic daily headache. Curr Pain Headache Rep. 2009;13(1):59-63.

21. Schultz AB, Edington DW. Employee health and presenteeism: a systematic review. J Occup Rehabil. 2007;17(3):547-79.

22. Bigal ME, Bigal JOM, Bordini CA, Speciali JG. Prevalence and costs of headaches for the public health system in a town in the interior of the state of São Paulo. Arq Neuropsiquiatr. 2001;59(3A):504-11.

23. Raak R, Raak A. Work attendance despite headache and its economic impact: a comparison between two workplaces. Headache. 2003;43(10):1097-101.

24. Schwartz BS, Stewart WF, Lipton RB. Lost workdays and decreased work effectiveness associated with headache in the workplace. J Occup Environ Med. 1997;39(4):320-7.

25. Hawkins K, Wang S, Rupnow M. Direct cost burden among insured US employees with migraine. Headache. 2008;48(4):553-63.

26. Lipton RB, Silberstein SD, Stewart WF. An update on the epidemiology of migraine. Headache. 1994;34(6):319-28.

27. Michel P, Dartigues JF, Lindoulsi A, Henry P. Loss of productivity and quality of life in migraine sufferers among French workers: results from the GAZEL cohort. Headache. 1997;37(2):71-8.

28. Mannix LK, Solomon GD, Kippes CM, Kunkel RS. Impact of headache education program in the workplace. Neurology. 1999;53(4):868-71.

Conflict of interest: None

Sources of funding: None

Date of first submission: January 28,2010

Last received: November 5, 2010

Accepted: December 16, 2010

Address for correspondence:

Juliana Stuginski-Barbosa

Rua Antônio Modenezi, 1.239

São Joaquim - Franca (SP) - Brasil

CEP $14406-310$

Tel. (+55 16) 3720-2090

E-mail: juliana.dentista@gmail.com 